\title{
CHRONOLOGY OF THE BURIAL FINDS FROM SCYTHIAN MONUMENTS IN SOUTHERN SIBERIA AND CENTRAL ASIA
}

\author{
A. A. SEMENTSOV, ${ }^{1}$ G. I. ZAITSEVA, ${ }^{1}$ J. GÖRSDORF, ${ }^{2}$ A. NAGLER, ${ }^{2}$ H. PARZINGER, ${ }^{2}$ \\ N. A. BOKOVENKO, ${ }^{1}$ K. V. CHUGUNOV ${ }^{1}$ and L. M. LEBEDEVA ${ }^{1}$
}

\begin{abstract}
We present here new radiocarbon dates for the different barrows (burial mounds) of the nomadic tribes of the Scythian period in the Khakassia and Tuva regions (Central Asia). The time scale of these barrows is compared with the elite barrows of the Sayan-Altai. In agreement with archaeological evidence, some barrows in Khakassia are chronologically close in time to the Arzhan barrow. The first ${ }^{14} \mathrm{C}$ dates produced for the barrows from the Tuva region belong to a later Scythian period, compared with the elite Arzhan barrow. We determined the final stage of the barrow construction, but to establish the starting time, more dates are necessary (both by dendrochronology and ${ }^{14} \mathrm{C}$ ).
\end{abstract}

\section{INTRODUCTION}

Establishing the chronology of the monuments from the Scythian period in Southern Siberia and Central Asia has been one of the most important archaeological problems studied over the past few years. Contact between the European and Central Asian Scythian cultures is no longer disputed, but how the contact took place is still unresolved. Therefore, the chronology of the cultures of the Scythian period is always at the center of the researchers' interest. Most important for the Scythian cultures of Central Asia are the elite barrows (burial mounds) in Sayan-Altai, especially those of the Arzhan (Tuva) and Pazyryk (Altai), because they are at a key position in the chronology (Gryaznov 1992). The origin and development of the Scythian culture are evident from different finds from the barrows both in Europe and in Asia. Typological resemblances in artifacts from different monuments, representing special periods of the Scythian epoch, have been found for wide territories in Eurasia. The materials from the Arzhan tsar barrow (Tuva) make it possible to study the initial stage of the cultural formation of the Scythian nomads in the steppe zones of southern Siberia and central Asia. Finds from the tsar barrow Pazyryk (Altai) reflected a later stage of Scythian nomadic culture than the Arzhan barrow. Archaeological-chronological reconstruction of the Scythian epoch is based on both barrows.

The chronological questions of the Scythian culture have been discussed for several decades. To establish a time scale for the Central Asian Scythian cultures, it is necessary to include the dates for monuments from the neighboring regions, among them Khakassia and Tuva. A new series of ${ }^{14} \mathrm{C}$ dates for these regions was obtained, allowing for a common ${ }^{14} \mathrm{C}$ time scale for the Scythian cultures in southern Siberia and Central Asia.

\section{RESULTS}

Figure 1 shows the location of the monuments investigated. We note that the Minusinsk valley, often called the Troy of Siberia, is situated in the south of Krasnoyarsk and Khakassia. It is home to a concentration of monuments belonging to different cultures from the Scythian period. The region connects Altai and Central Asia and is characterized by special environmental conditions that influenced the ancient nomadic cultures. The Tuva monuments are mostly located in the steppe valleys of the upper Enisey basin. ${ }^{14} \mathrm{C}$ dating of samples from the monuments in this region was performed

\footnotetext{
${ }^{1}$ The Institute of the History of Material Culture of the Russian Academy of Sciences, Dvortsovaya nab.18, St. Petersburg 191186 Russia

${ }^{2}$ German Institute of Archaeology, Euro-Asia Department, PO Box 330014, D-14191 Berlin, Germany
} 
by ${ }^{14} \mathrm{C}$ labs at the Institute of the History of Material Culture (St. Petersburg) and the German Institute of Archaeology (Berlin). They dated samples from different monuments and sites to learn more about the occupation of this region during the pre-Scythian and Scythian periods.

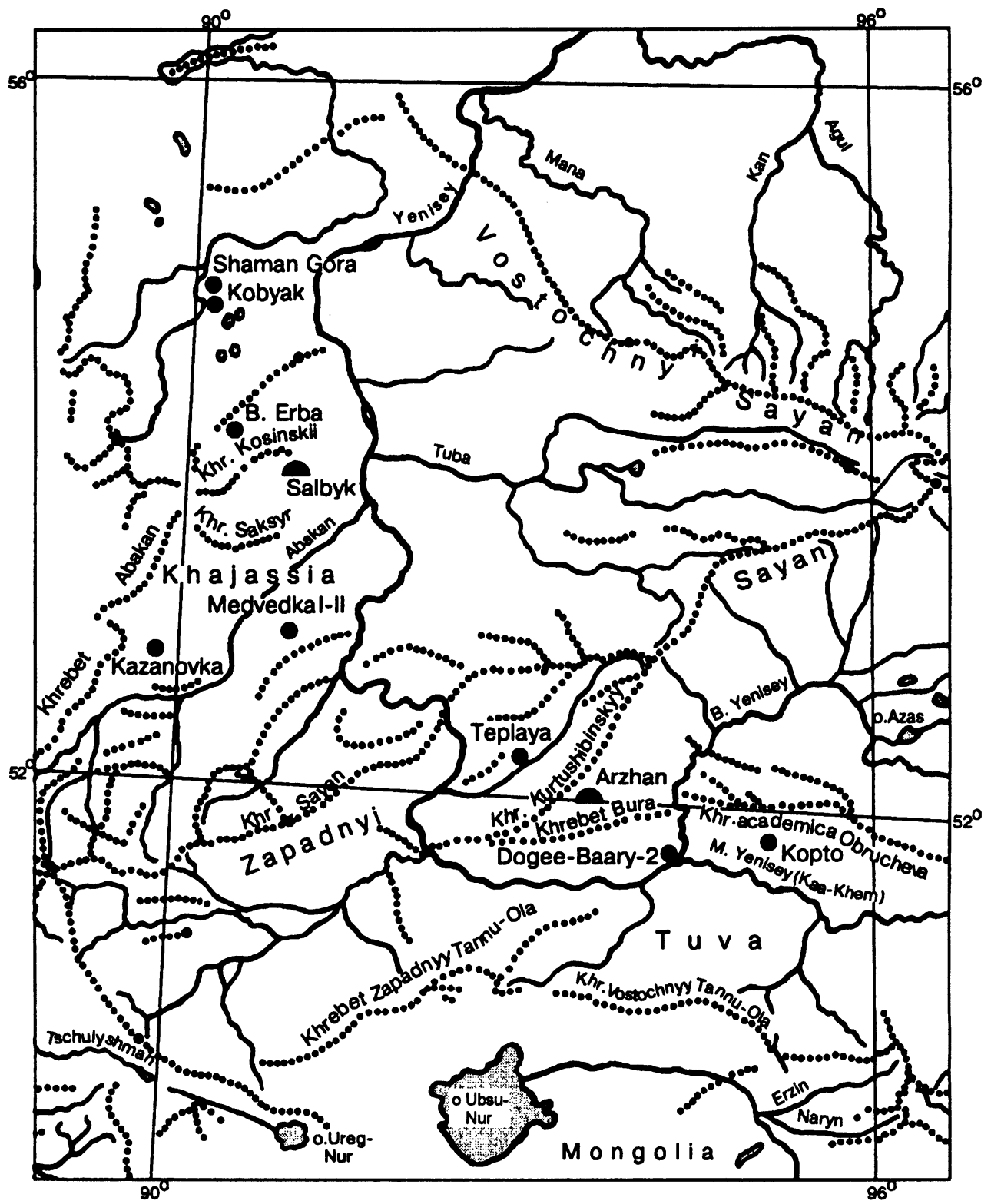

Fig. 1. Map showing the location of the investigated barrows. $=$ the elite barrows, the key monuments for the Scythian period. $=$ barrows under investigation. 
TABLE $1 .{ }^{14} \mathrm{C}$ dates for the Monuments of Southern Siberia and Central Asia

\begin{tabular}{|c|c|c|c|c|c|c|c|}
\hline \multirow[b]{2}{*}{ No. } & \multirow[b]{2}{*}{ Lab code } & \multirow{2}{*}{$\begin{array}{l}{ }^{14} \mathrm{C} \text { age } \\
\text { (yr BP) }\end{array}$} & \multirow[b]{2}{*}{ Barrow name } & \multirow[b]{2}{*}{ Material } & \multirow[b]{2}{*}{ Tree-ring material } & \multicolumn{2}{|c|}{$\begin{array}{c}\text { Intervals of } \\
\text { calibrated age, BC }\end{array}$} \\
\hline & & & & & & 10 & $2 \sigma$ \\
\hline \multicolumn{8}{|c|}{ Khakassia } \\
\hline 1. & Le-5133 & $2840(35)$ & B.Erba, b.4/g.2 & Wood & -- & 1012-926 & 1114-1094 \\
\hline 2. & Le-5135a & $2780(40)$ & B.Erba,b.4/g2 & Wood & $\begin{array}{l}\text { Ca. } 100 \text { tree rings; } 20 \\
\text { outside tree rings dated }\end{array}$ & $\begin{array}{l}984-962 \\
934-892\end{array}$ & $\begin{array}{l}1072-906 \\
1000-832\end{array}$ \\
\hline 3. & Le-5135b & $2730(25)$ & B.Erba, b.4/g2 & Wood & $\begin{array}{l}\text { Ca. } 100 \text { tree rings; } 30 \\
\text { inside tree rings dated }\end{array}$ & $\begin{array}{l}882-846 \\
900-830\end{array}$ & $906-820$ \\
\hline 4. & Le-5192 & $2700(30)$ & $\begin{array}{l}\text { Shaman-Gora, } \\
\text { b.1/g.2 }\end{array}$ & Wood & -. & $\begin{array}{l}894-882 \\
846-810\end{array}$ & $900-864$ \\
\hline 5. & Le-5137 & $2665(30)$ & Kazanovka-2, b.3/ A & Wood & -- & $\begin{array}{l}846-810 \\
826-802\end{array}$ & $\begin{array}{l}862-806 \\
894-880\end{array}$ \\
\hline 6. & Le-5134b & $2840(30)$ & Kobyak b.5/g.1 & Wood & Ca. 100 tree rings; 18 & $1006-974$ & $\begin{array}{c}848-796 \\
1111-1102\end{array}$ \\
\hline 7. & Le-5134a & $2790(35)$ & Kobyak b.5/g.1 & Wood & $\begin{array}{l}\text { central tree rings dated } \\
\mathrm{Ca} .100 \text { tree rings, } 20 \\
\text { middle tree rings dated }\end{array}$ & $\begin{array}{l}972-930 \\
990-956 \\
840-900\end{array}$ & $\begin{array}{l}1052-908 \\
1000-840\end{array}$ \\
\hline $\begin{array}{l}8 . \\
9 .\end{array}$ & $\begin{array}{l}\text { Le-5191 } \\
\text { Le-5190 }\end{array}$ & $\begin{array}{l}2640(25) \\
2470(30)\end{array}$ & $\begin{array}{l}\text { Kobyak, b.5/g.1 } \\
\text { Kobyak, b.5/g.2 }\end{array}$ & $\begin{array}{l}\text { Wood } \\
\text { Wood }\end{array}$ & $\begin{array}{l}-- \\
--\end{array}$ & $\begin{array}{l}872-854 \\
814-800 \\
762-674\end{array}$ & $\begin{array}{l}824-794 \\
764-618\end{array}$ \\
\hline & & & & & & $664-630$ & $606-742$ \\
\hline & & & & & & $592-580$ & $458-412$ \\
\hline & & & & & & $534-512$ & \\
\hline 10. & Le-5138 & $2650(90)$ & Medvedka-2, b.1/g.1 & Fur & From clothes & $\begin{array}{l}440-420 \\
920-762\end{array}$ & $1002-514$ \\
\hline & & & & & & $670-666$ & $438-422$ \\
\hline 11. & Le-5139 & $2580(50)$ & Medvedka-2, b.1/g.1 & Textile & From clothes & $\begin{array}{l}630-594 \\
810-760\end{array}$ & $824-752$ \\
\hline & & & & & & $674-664$ & $730-710$ \\
\hline & & & & & & $630-592$ & $706-528$ \\
\hline 12. & Le-2007 & $2560(40)$ & Medvedka-2, b.1/g.1 & Wood & 12 central tree rings & $\begin{array}{l}580-556 \\
802-762\end{array}$ & $808-752$ \\
\hline & & & & & & $674-664$ & $700-530$ \\
\hline & & & & & & $630-594$ & \\
\hline 13. & Le-5140 & $2540(60)$ & Medvedka-2, b.1/g.1 & Charcoal & -- & $\begin{array}{l}580-556 \\
798-756\end{array}$ & $806-484$ \\
\hline 14. & Le-2007a & $2520(40)$ & Medvedka-2, & Wood & $12-24$ central tree rings & $\begin{array}{l}686-540 \\
778-758\end{array}$ & $\begin{array}{l}446-416 \\
798-516\end{array}$ \\
\hline 15. & Le-2190 & $2490(40)$ & $\begin{array}{l}\text { b. } 3 / g 12 \\
\text { Medvedka-2, b.2/g.1 }\end{array}$ & Wood & - & $\begin{array}{l}682-544 \\
764-752\end{array}$ & $\begin{array}{l}436-422 \\
778-478\end{array}$ \\
\hline & & & & & & $730-710$ & $452-414$ \\
\hline & & & & & & $708-618$ & \\
\hline 16. & Le-2191 & $2470(40)$ & Medvedka-2, b.2/g.2 & Wood & -- & $\begin{array}{l}606-528 \\
762-670\end{array}$ & $764-616$ \\
\hline & & & & & & $668-630$ & $606-412$ \\
\hline & & & & & & $594-576$ & \\
\hline & & & & & & $558-508$ & \\
\hline 17. & Le-2036 & $1980(40)$ & $\begin{array}{l}\text { Medvedka-1, } \\
\text { b.1/g. } 2\end{array}$ & Wood & -- & $\begin{array}{l}442-418 \\
2 \text { BC-AD } 76\end{array}$ & $\begin{array}{l}44 \text { BC-AD } 88 \\
\text { AD } 96-120\end{array}$ \\
\hline 18. & Le-2040 & $2060(40)$ & $\begin{array}{l}\text { Medvedka-1, } \\
\text { b.1/g.2 }\end{array}$ & Wood & -- & $106 \mathrm{BC}-\mathrm{AD} 2$ & $\begin{array}{l}74 \text { BC-AD } 22 \\
\text { AD } 42-56\end{array}$ \\
\hline 19. & Le-2045 & $2030(40)$ & Medvedka-1, b.4 & Wood & -- & $56 \mathrm{BC}-\mathrm{AD} 22$ & AD 154-146 \\
\hline & & & & & & AD 40-56 & $116 \mathrm{BC}-72 \mathrm{AD}$ \\
\hline
\end{tabular}


TABLE $1 .{ }^{14} \mathrm{C}$ dates for the Monuments of Southern Siberia and Central Asia (Continued)

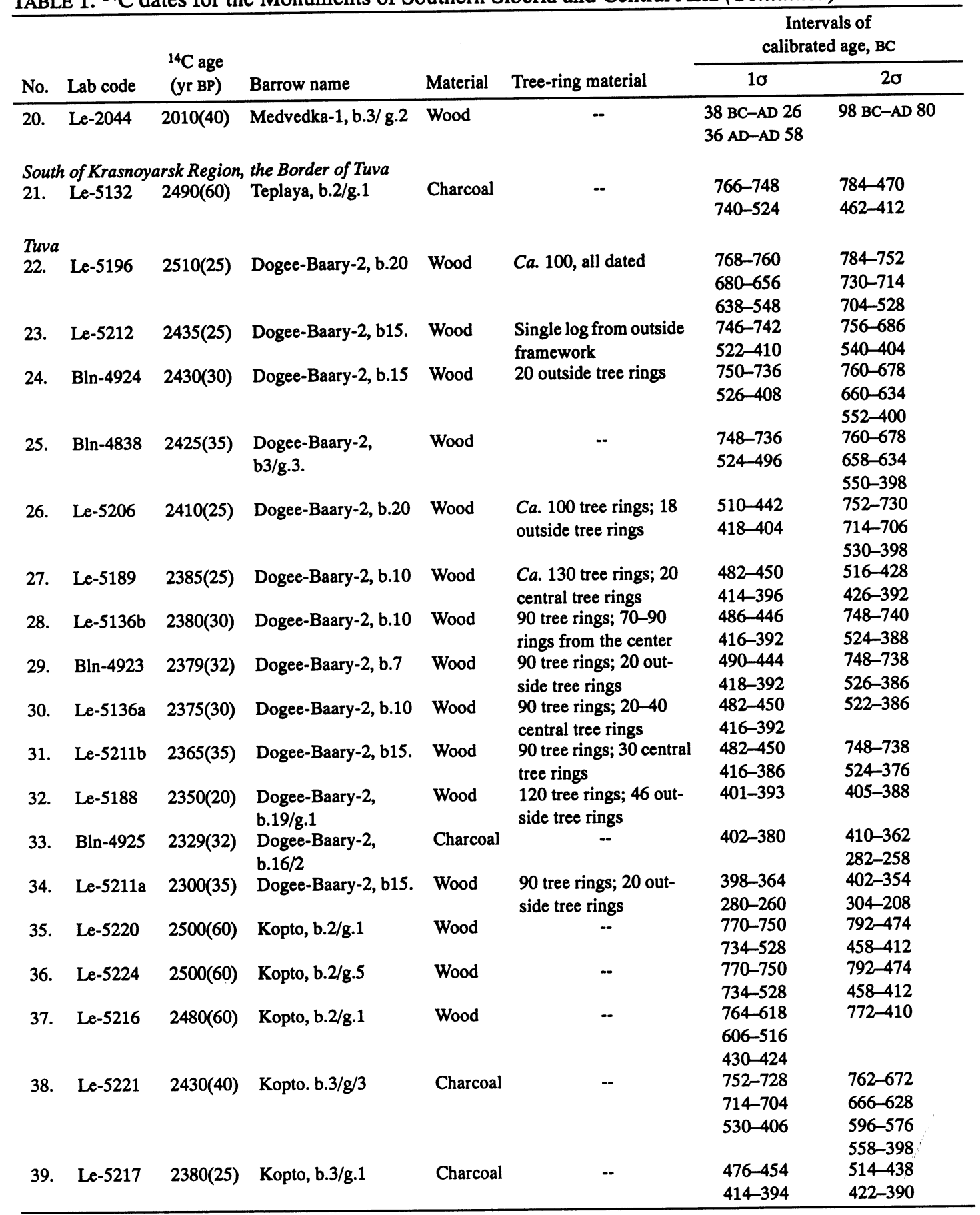


Table 1 lists the new ${ }^{14} \mathrm{C}$ dates. Until now, the chronology of the Scythian cultures in Tuva was based on ${ }^{14} \mathrm{C}$ dates for the Arzhan barrow. The first ${ }^{14} \mathrm{C}$ data set was produced for other Tuva monuments which, according to archaeological materials, belong to a period of Scythian culture that is later than the that of the Arzhan barrow. Among these Tuva dates are the barrows Dogee-Baary-2 and Kopto, recently excavated by K. Chugunov (Chugunov 1995). The Dogee-Baary-2 monument consists of two rows of barrows: the first row is barrows no. 1-15; the other is no. 15-19. There is also a separate barrow-no. 20. The Kopto monument contains three barrows connected by stratigraphy; their construction indicates early Scythian traditions.

The most interesting monument is the Teplaya barrow, located on the border of southern Siberia and Tuva (the mountains of Western Sayan). The environmental conditions of this region are similar to Tuva, and artifacts from the Teplaya barrow are typologically analogous to material from the Tuva monuments (Bokovenko 1994).

\section{Discussion}

The elite barrows Arzhan and Pazyryk from the early and later periods of the Scythian epoch for southern Siberia and Central Asia form the basis of prehistoric and chronological studies. Large series of ${ }^{14} \mathrm{C}$ dates and dendrochronological determinations for these barrows have been produced (Marsadolov 1988; Marsadolov, Zaitseva and Lebedeva 1994; Zaitseva et al. 1996). Figure 2 shows the distribution of ${ }^{14} \mathrm{C}$ dates for these monuments. These data show that the main time interval is from $2800 \mathrm{BP}$ up to $2400-2300 \mathrm{BP}$, corresponding to $800-400 \mathrm{BC}$. It is important to determine the date of the barrows investigated here with respect to the key barrows from the Scythian period.

${ }^{14} \mathrm{C}$ dates have only recently been obtained for the grave mounds Bol'shaya Erba, Kazanovka-2, Kobyak and Shaman Gora, which belong to the early part of the Tagar culture from the Scythian period. Most of these monuments were excavated by N. Bokovenko from 1989 to 1995 (Bokovenko, Kuzmin and Lazaretov 1993). The finds from these monuments typologically resemble materials from the Arzhan barrow. In general, these barrows were archaeologically dated at 7 th-6th century BC (Bokovenko 1995), which is somewhat later than the Arzhan barrow. This was contradicted by the archaeological view of the development of the nomadic cultures in Southern Siberia. Now, our results show that the age of these barrows is close to the age of the Arzhan barrow, thus solving the controversy.

Two ${ }^{14} \mathrm{C}$ dates for the Kobyak barrow are older than what had been assumed based on archaeological materials. This can be explained by the old-wood effect: ${ }^{14} \mathrm{C}$ dates were obtained for samples from the central tree rings of a log from a wooden construction. According to the ${ }^{14} \mathrm{C}$ results, the Kobyak monument is dated close in time to the Tagar culture.

From the mound Medvedka-2, grave 1, different materials have been analyzed: charcoal, wood, burned fur and textile. The dates fall in the time interval from the 9th-5th century BC. The most probable time for building this grave is at the end of this time interval, based on archaeological evidence. The large interval of calendar time can be explained by the complicated nature of the calibration curve at this time (Fig. 3). We note that the wood samples from Medvedka-2, grave 1 were dated in the 1980s. The dates obtained now are in the same time range (see Table 1).

The Medvedka barrow complexes consist of two cemeteries: No. 1 and No. 2 (Bokovenko et al. 1988). The earlier one (the Medvedka-2 barrows) is located close to mountains and was constructed earlier than the Medvedka- 1 barrows located in the steppe zone. The ${ }^{14} \mathrm{C}$ data has confirmed this succession of barrow constructions. 


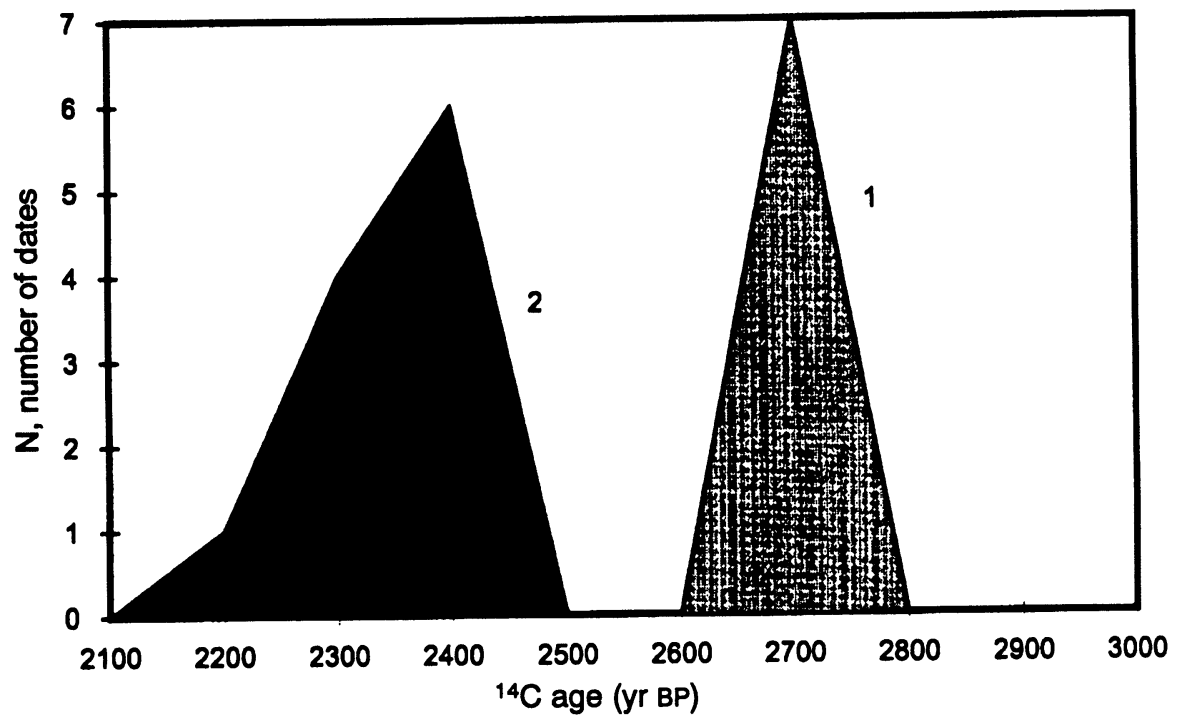

Fig. 2. The distribution of ${ }^{14} \mathrm{C}$ dates for the Arzhan and Pazyryk barrows (Marsadolov, 1994). 1=Arzhan; 2=Pazyryk.

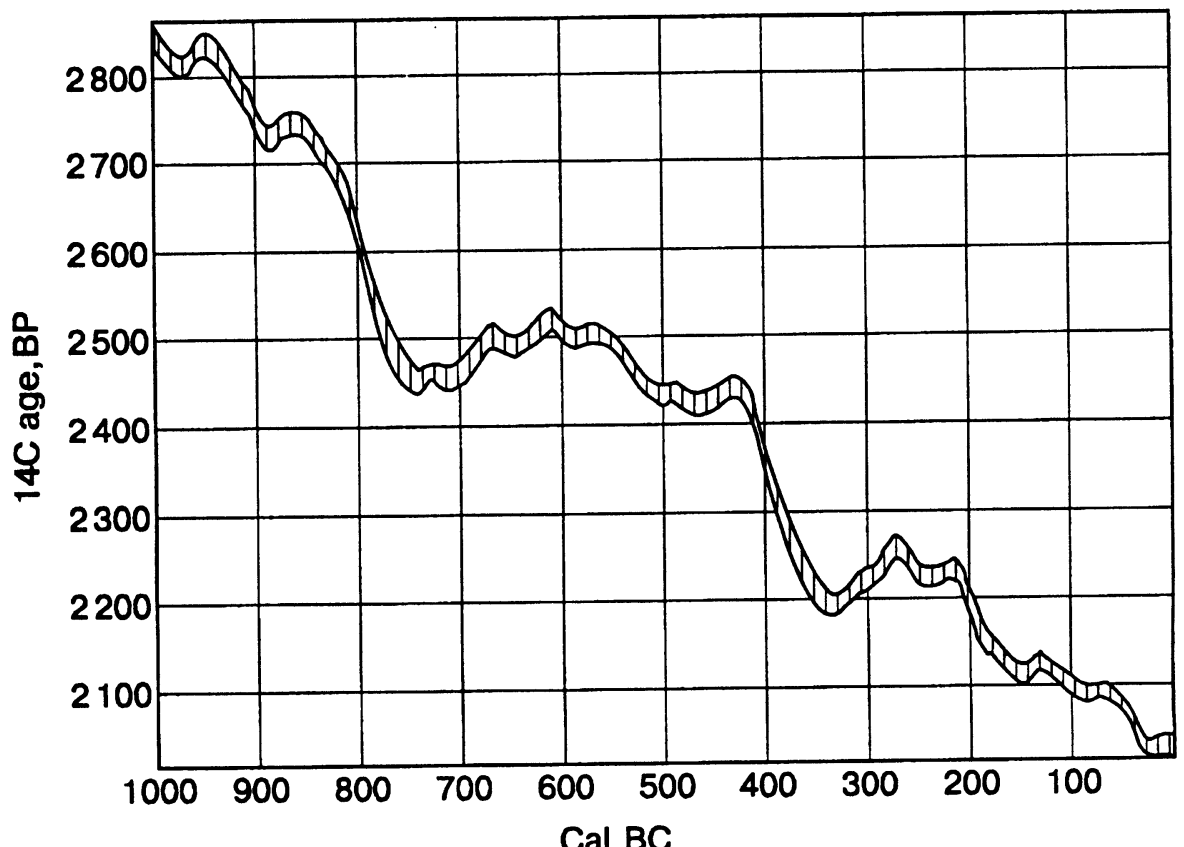

Fig. 3. The part of the calibration curve for the intervals of measured ${ }^{14} \mathrm{C}$ dates (Stuiver and Pearson 1986; Pearson and Stuiver 1986) 
The time intervals for the barrow constructions located in the Minusinsk Valley, which belong to different periods of the Scythian culture, is from 10th-8th century BC to the 1st century AD. It is clear that Vadezkaya and Kuzmin are correct in their assumptions (Vadezkaya 1995; Kuzmin 1994) about the large time range for the final stage of the Tagar culture; this is confirmed by the new ${ }^{14} \mathrm{C}$ dates.

For the Tuva region, the Dogee-Baary-2 and Kopto monuments were selected for investigation. Both the Dogee-Baary-2 and Kopto barrows are connected with a culture called "Uyuk-Salgynskyi". The Kopto barrow is considered to belong to an earlier culture of the Scythian period called "Aldy-Bel'skaya". Most of the wood samples from the Dogee-Baary-2 barrow have ${ }^{14} \mathrm{C}$ ages $\mathrm{ca}$. $2400 \mathrm{BP}$, which is close to the ${ }^{14} \mathrm{C}$ age of the Pazyryk group barrows (Table 1 ). The ${ }^{14} \mathrm{C}$ dates confirm that the Kopto and Dogee-Baary-2 barrows are chronologically close to each other, despite some differences in burial rites. Our data show that the two cultures mentioned above co-existed. Previously, some archaeologists thought that the Dogee-Baary-2 barrows were built later than the Kopto
barrows.

To transform the ${ }^{14} \mathrm{C}$ age into calendar time, we used the Stuiver calibration curve (Stuiver and Pearson 1986; Pearson and Stuiver 1986). The part of this curve corresponding to the range of ${ }^{14} \mathrm{C}$ dates for the barrows under investigation is shown in Figure 3. The dates for barrow 19, grave 1, confirm that the final stage of construction of this barrow was at the end of the 5th-beginning of 4th century BC. Other dates fall within the complicated part of the calibration curve where the rather close ${ }^{14} \mathrm{C}$ values correspond to a wide interval of calendar time. Therefore, it is rather difficult to determine the time of the construction for the Dogee-Baary-2 barrows. This problem can be solved by combining ${ }^{14} \mathrm{C}$ and dendrochronology. We note that the finds from the Dogee-Bary-2 and Kopto barrows are not as well preserved as those from the barrows of the Arzhan and Pazyryk type. Here, the finds have been preserved under permafrost conditions. Nevertheless, the tree rings of the wood constructions can be selected and measured.

Our next task will be the creation of the floating tree-ring scale for the Dogee-Baary- 2 barrows, and the connection with the time scale obtained for the key monuments in Sayan-Altai. A more detailed determination of the calendar time for the Dogee-Baary-2 and Kopto barrows can be obtained by dating samples from wood remains spanning ca. 10-20 rings and wiggle-matching results to the bidecadal calibration curves (Stuiver and Pearson 1986; Pearson and Stuiver 1986).

The new ${ }^{14} \mathrm{C}$ results prove that the Scythian nomads occupied a wide territory of Southern Siberia over a long period of time. The initial stage of this culture is presented by the monuments from Khakassia (Kobyak, B. Erba, Kazanovka and Shaman Gora barrows), southern Siberia (Teplaya barrow) and Tuva (Arzhan barrow). The final stage of the Scythian culture is represented by monuments from Khakassia (Medvedka-2,1 barrows), Tuva (the Dogee-Baary-2 and Kopto barrows) and the Gornii Altai region (Pazyryk barrows). The data set obtained can serve as the starting point for the creation of a united ${ }^{14} \mathrm{C}$ time scale for southern Siberia and Central Asia.

\section{ConClusion}

The chronology of the cultures from the Scythian period was based thus far on data from the key monuments Arzhan (Tuva) and Pazyryk (Altai). The ${ }^{14} \mathrm{C}$ dates obtained for the monuments of Khakassia allow us to add new data to the common time scale for the nomadic cultures of the Scythian time period in Southern Siberia and Central Asia. These new dates make it possible to synchronize the earlier Scythian monuments over a wide territory and to solve some of the contradictions that exist when only the traditional archaeological chronology is used. The first ${ }^{14} \mathrm{C}$ dates were obtained for the barrows in Tuva (Dogee-Baary-2 and Kopto), showing that the Scythian-type barrows were 
constructed in the Pazyryk period. To determine the starting time for the constructions, both treering and ${ }^{14} \mathrm{C}$ chronologies must be improved.

\section{ACKNOWLEDGMENTS}

The research is supported by the Russian Foundation of Fundamental Research, Grant No. 96-06$00001 G$ and the German Scientific Research Society, Grant No. GO 707/3-1//436 RUS 113/232/0(R).

\section{REFERENCES}

Bokovenko, N. A. 1994 Tomb of Saka princes discovered in the Sayan, Siberia. In Masson, V. M., Kozintsev, A. G., Solovyova, N. F. and Zuyev, V. Yu., eds., New Archaeological Discoveries in Asiatic Russia and Central Asia. Archaeological Studies 16: 48-54.

199511 New Archaeological discoveries in Western Siberia. In Investigation of Cultural Interactions and Archaeological Discoveries. St. Petersburg: 3739 (in Russian).

Bokovenko, N. A. and Krasnienko, S. V. 1988 The mound Medvedka-2. The Archaeological Sites in $\mathrm{Me}$ lioration Zone of Southern Siberia. Leningrad, Nauka: 23-46 (in Russian).

Bokovenko, N. A., Kuzmin, N. Yu. and Lazaretov, I. P. 1993 New archaeological discoveries in Khakassia. In New Discoveries and Methodological Foundations of Archaeological Chronology. St. Petersburg: 25-28 (in Russian).

Chugunov, K. V. 1995 The investigation of the burial mound of Dogee-Baary in Tuva. Archaeological Discoveries of 1994. Moscow, Nauka: 312-313 (in Russian).

Gryaznov, M. P. 1992 Altai and the Altaian Steppe. In Moskva, M. G., ed., Archaeology of the USSR: Steppe Zone of the Asian Part of the USSR in the Scythian and Sarmathian Time. Moscow, Nauka: 161-178 (in Russian).

Kuzmin, N. 1995 The results, problems and aims of the study of tes' burial monuments in Khakassia. In Southern Siberia in the Ancient Time. Archaeological Studies 24: 151-163 (in Russian).

Kuzmin, N. Yu. 1994 The Barrow Near Novom ikhailovka Village. Problems of the Study of the Steppe
Tribes' Culture along the Yenisey, V-III Centuries BC. St. Petersburg (in Russian).

Marsadolov, L. S. 1988 The tree-ring chronology of the great barrows of Sayan-Altai (1st millennium BC). Archaeological News of the State Hermitage 29: 65-81 (in Russian).

Marsadolov, L. S., Zaitseva, G. I., Lebedeva, L. M. 1994 The correlation of tree-ring chronology and radiocarbon data for the great barrows of Sayan-Altai. In Alexeev, A., Bokovenko, N. A. and Marsadolov, L. S., eds., Elite Barrows of Eurasian Steppe in Scythian and Sarmathian Epoch. St. Petersburg: 141-157 (in Russian).

Pearson, G. W. and Stuiver, M. 1986 High-precision calibration of the radiocarbon time scale, 500-2500 BC. In Stuiver, M. and $\mathrm{Kra}, \mathrm{R}$., eds., Calibration Issue. $R a-$ diocarbon 28(2B): 839-862.

Stuiver, M. and Pearson. G. W. 1986 High-precision calibration of the radiocarbon time scale, AD 1950-500 BC. In Stuiver, M. and Kra, R., eds., Calibration Issue. Radiocarbon 28(2B): 805-838.

Vadezkaya, E. B. 1992 Tashtyk culture. The Archaeology of the USSR: Steppe Zone of the Asian Part of the USSR in the Scythian-Sarmathian Time. Moscow, Nauka: 236-247 (in Russian).

Zaitseva, G. I., Vasiliev, S. S., Marsadolov, L. S., Sementsov, A. A., Dergachev, V. A. and Lebedeva, L. M. 1996 The use of mathematical-statistic method for the correlation of tree-ring and radiocarbon chronology (on the base of the materials of elite barrows of SayanAltai). Radiocarbon and Archaeology 1: 33-38 (in Russian). 